\title{
Antioxidant properties of Ageratum conyzoides L. Asteraceae leaves
}

\author{
F. O. Adetuyi*, K. O. Karigidi, E. S. Akintimehin and O. N. Adeyemo \\ Biochemistry unit, Chemical Sciences, Ondo State University of Science and Technology, PMB 353, Okitipupa, Ondo State,
} Nigeria.

\section{Abstract}

Received: 18 June 2017

Revised: 24 September 2017

Accepted: 31 January 2018

DOI: http://dx.doi.org/10.3329/bjsir.v53i4.39190
In vitro antioxidative and anti-lipid peroxidative properties of aqueous and methanol extracts of Ageratum conyzoides leaves were studied in controlling erectile dysfunction caused by oxidative stress. Methanol extract gave a significantly $(P<0.05)$ higher content of total phenolic $(61.4$ mgGAE/g), total flavonoid (42.2 mgQE/g), ascorbic (10.1 mgAAE/100g) and phosphomolybdate (45.8 $\mathrm{mgAAE} / \mathrm{g}$ ) than the aqueous extract. The result showed that the extracts have high antioxidant activities. However, the methanol extract showed a higher DPPH and hydrogen peroxide scavenging activities over aqueous extract but the aqueous extract had a higher reducing power. The methanol extract exhibited a greater inhibition against lipid peroxidation induced by $\mathrm{Fe}^{2+}$ in rat pancreas and penile tissue homogenate exemplified by their least IC50 $(94.21 \mu \mathrm{g} / \mathrm{ml}$ in pancreas) and $(75.95$ $\mu \mathrm{g} / \mathrm{mL}$ in penile tissue) while in rat brain homogenate the aqueous extract exhibited a greater inhibition against lipid peroxidation induced by $\mathrm{Fe}^{2+}$ with least IC50 of $91.74 \mu \mathrm{g} / \mathrm{mL}$. Hence, these extracts can be used as a potent natural antioxidant against free radicals and as a natural source of combating erectile dysfunction caused by oxidative stress. The extracts of Ageratum conyzoides leaves could be useful therapeutically as erectogenic agent.

Keywords: A. conyzoides; Antioxidants; Aqueous; Methanol; Total phenol and $\mathrm{Fe}^{2+}$ induced lipid peroxidation

\section{Introduction}

Erectile dysfunction (ED) means a condition where there is consistent inability in man to get and/or maintain penile erection in order to have a satisfactory sexual performance (NIH Consensus Conference 1993). 150 million men is estimated globally to have suffered from ED and this could rise to 322 million in the year 2025 (Kassier and Veldman, 2014). Normal erection is a function of adequate balance between these factors: psychology, neurology, vascular hormone and corpus cavernous. Hence if this balance in these factors is altered it can lead to ED (Agarwal et al., 2006). One important factor in penile erection is nitric oxide (NO). Erectile function depends on the relaxation of the corpus cavernous (CC) smooth muscle which the mechanism is mediated by NO (Agarwal et al., 2006). ED normally is described as a decrease in nitric oxide (NO) bioavailability which can be due to reduction in the function of the enzyme nitric oxide synthase present in the endothelial known as eNOS (endothelial nitric oxide synthase) and/or increase in the removal of NO (Sasatomi et al., 2008). Oxidative stress is a situation where pro-oxidants activities and the antioxidant capacity in scavenging excess reactive oxygen species (ROS) is not balanced (Agarwal et al., 2006). Oxidative stress can induce ED when peroxynitrite which causes reductions in NO bioavailability are produced as a result of interaction of ROS like superoxide anion with nitric oxide (NO) (Haffner et al., 1998). The peroxynitrite formed and superoxide radicals may cause apoptosis in the endothelium, damage the endothelium of the corpus cavernosal $\mathrm{CC}$ smooth muscle and result in the reduction of NO availability (Ferreira et al., 2006). The consumption of natural antioxidant rich foods like fruits and vegetables could help in fighting against this oxidative stress (Adefegha et al., 2016).

\footnotetext{
*Corresponding author e-mail: foluadetuyi@yahoo.co.uk
} 
Ageratum conyzoides L. is a medicinal plant that belongs to the family Asteraceae. They are found close to habitation especially where waste are deposited, they thrives on any garden soil and on ruined sites. The odour of Ageratum conyzoides is likened to that of a male goat, therefore the name 'goat weed' or 'billy goat weed' was derived (Okunade, 2002). Ageratum conyzoides (L.) have been used traditionally as a medicine over a long period of time and the use varies from one region to another (Adebayo et al., 2010; Okunade, 2002). In Nigeria it is used in treating skin diseases and wound healing. Also, a decoction of the plant when taken by children is used in the treatment of diarrhea and relieving the pains associated with navel (Okunade, 2002). In Central Africa, it is used as remedy for pneumonia, but used commonly in treating wounds and burns (Vaidyaratnam-Varier, 2002). In India, A.conyzoides is used in treating leprosy, in Brazil it is used as anti-inflammatory, analgesic and anti-diarrhoea while in Vietnam it is used for treating gynecological diseases (Okunade, 2002).

To our knowledge, there has been no previous study to directly evaluate the antioxidative, erectogenic, and anti-lipid peroxidative properties of Ageratum conyzoides leaf extracts. However, a lot of work has been done on Ageratum conyzoides L. by different researchers in-vivo. The crude leaf extract of Ageratum conyzoides has been found to have neuromuscular blocking and analgesic activities in rat. Anti inflammatory, analgesic and antipyretic activities of the essential oil of Ageratum conyzoides in mice and rats has been reported. The haemopoietic properties of the ethanol extract have also been reported in albino rats. The aqueous leaf extract possess hypoglycaemic or anti-diabetic and kidney protecting effects in Albino Rats have been reported. It has been reported that $A$. conyzoides L. leave extract had anti-peptic ulcer activity against ethanol induced gastric ulceration and cysteamine induced duodenal ulcerations in rats. Petroleum ether extracts of Ageratum conyzoides has also been found effective against the mosquito Culex quinquefasciatus larvae (Abena et al., 1996; Ita et al., 2007; Mitra, et al., 2015; Agbafor, et al., 2015). The present study is aimed at evaluating the antioxidative and anti-lipid peroxidative properties of aqueous and methanol extracts of
Ageratum conyzoides leaves in combating erectile dysfunction caused by oxidative stress.

\section{Materials and methods}

\section{Sample collection}

Fresh leaves of Ageratum conyzoides were harvested from Ondo State University of Science and Technology (OSUSTECH) farm, Okitipupa, Ondo State, Nigeria. It was identified and authenticated at the herbarium of Biological Sciences Department, OSUSTECH.

\section{Extract preparation}

The leaves collected were air dried for two weeks and it was grounded into powder. Fifty grams $(50 \mathrm{~g})$ each of the grounded powder was soaked in $250 \mathrm{~mL}$ distilled water and methanol respectively for $24 \mathrm{~h}$ and the mixture was shaken intermittently. The resulting mixture was filtered using a muslin cloth. The filtrate was concentrated using rotary evaporator at $40^{\circ} \mathrm{C}$ and concentrated samples were used for analyses immediately.

\section{In vitro antioxidant assays}

\section{Estimation of total phenolic content}

The total phenolic content was determined spectrophotometrically using the method of Kim et al. (2003). It is described thus: $1 \mathrm{~mL}$ of the sample $(1 \mathrm{mg} / \mathrm{mL})$ was mixed with $1 \mathrm{ml}$ of Folin-Ciocalteu phenol reagent (1:15). After $5 \mathrm{~min}, 5 \mathrm{~mL}$ of a $7 \% \mathrm{Na}_{2} \mathrm{CO}_{3}$ solution was added to the mixture then $6.5 \mathrm{ml}$ of distilled water was added, it was then mixed thoroughly. This was kept in the dark for 90 minutes at $25^{\circ} \mathrm{C}$; then the absorbance was taken at $750 \mathrm{~nm}$. The total phenolic content was determined from Gallic acid standard calibration curve. The estimation of the total phenolic content was in $\mathrm{mg}$ Gallic Acid Equivalents (GAE) per g.

\section{Estimation of total flavonoids content}

Total flavonoid content was determined according to Park et al. (2008) method. $1 \mathrm{~mL}$ of sample (1 mg/mL), $3.4 \mathrm{~mL}$ of 
$30 \%$ methanol, $0.15 \mathrm{~mL}$ of $\mathrm{NaNO}_{2}(0.5 \mathrm{M})$ and $0.15 \mathrm{~mL}$ of $\mathrm{AlCl}_{3} .6 \mathrm{H}_{2} \mathrm{O}(0.3 \mathrm{M})$ were taken mixed together and left for 5 minutes, then $1 \mathrm{ml}$ of $1 \mathrm{M} \mathrm{NaOH}$ was added. The solution was thoroughly mixed; the absorbance was taken at $506 \mathrm{~nm}$. The total flavonoid content was determined from Quercetin standard calibration curve. The total flavonoids were measured as mg Quercetin equivalent per $g$ of the extracts.

\section{Estimation of Ascorbic acid content}

Ascorbic acid was quantified using spectrophotometric method of Rutkowski et al. (2007). $2 \mathrm{~mL}$ of the sample was mixed with $4 \mathrm{~mL}$ of phosphotungstin reagent. The mixture was left for 10 minutes after which it was centrifuged at 3000 $\mathrm{x} g$ for 10 minutes. Then the absorbance of the supernatant was read at $700 \mathrm{~nm}$ against the reagent blank.

Ascorbic content $=($ Abs of the sample $/$ Abs of standard $) \times$ Concentration of standard

\section{Phosphomolybdate assay}

The total antioxidant capacity was determined by the phosphomolybdate method of Prieto et al. (1999). $1.0 \mathrm{~mL}$ (1 $\mathrm{mg} / \mathrm{mL}$ ) of the sample taken and mixed with $1 \mathrm{~mL}$ of phosphomolybdate reagent $(0.6 \mathrm{M}$ sulphuric acid, $28 \mathrm{mM}$ sodium phosphate and $4 \mathrm{mM}$ ammonium molybdate). Then it was incubated in a water bath at $95^{\circ} \mathrm{C}$ for $90 \mathrm{~min}$, cooled to room temperature, the absorbance was taken at $765 \mathrm{~nm}$ against a blank.

\section{Metal chelating activity}

Metal chelating activity is measured using the method of Dinis et al. (1994). $0.1 \mathrm{~mL}(20-100 \mu \mathrm{g} / \mathrm{mL})$ of the extract was taken and $0.5 \mathrm{~mL}$ of $2 \mathrm{mM}$ ferrous chloride was added, then $0.2 \mathrm{~mL}$ of $5 \mathrm{mM}$ ferrozine was added and incubated for 10 min at room temperature. The absorbance was measured at $560 \mathrm{~nm}$. EDTA was used as control.

Metal chelating ability $=[($ Abs control - Abs sample $) /($ Abs control) $] \times 100$

\section{Reducing power}

The reducing power was estimated using the method of Oyaizu (1986). $1.0 \mathrm{~mL}(0.25-1.0 \mathrm{mg} / \mathrm{mlL})$ of the extract was added to $1 \mathrm{~mL}$ phosphate buffer of $\mathrm{pH} 6.6$; then $1 \mathrm{~mL}$ of potassium ferricyanide $(10 \mathrm{mg} / \mathrm{mL})$ was added. The whole mixture was incubated at $50^{\circ} \mathrm{C}$ for $20 \mathrm{~min} .1 \mathrm{~mL}$ of trichloroacetic acid $(100 \mathrm{mg} / \mathrm{mL})$ was then added. The mixture was centrifuged at $3000 \mathrm{x} g$ for $10 \mathrm{~min}$; upper layer of the solution was collected. $2 \mathrm{~mL}$ was taken and mixed with $1 \mathrm{~mL}$ distilled water and $0.2 \mathrm{~mL}$ of $0.1 \%$ freshly prepared ferric chloride. After $10 \mathrm{~min}$, the absorbance was taken at 700 nm. Ascorbic acid was used as Standard.

\section{DPPH scavenging activity}

DPPH radical scavenging activity was estimated according to method of Gyamfi et al. (1999). $1.0(0.25-1.0 \mathrm{mg} / \mathrm{mL})$ of sample extracts were added to $4 \mathrm{~mL}$ of DPPH $(0.025 \mathrm{~g} / 1$ prepared in methanol solution). The sample was shaken and allowed to stand in the dark for $30 \mathrm{~min}$ and absorbance was taken at $520 \mathrm{~nm}$. The standard was Ascorbic acid and Quercetin.

DPPH scavenging ability $=[($ Abs control - Abs sample $) /$ (Abs control) $] \times 100$

\section{Hydrogen peroxide scavenging activity}

Hydrogen peroxide scavenging activity was estimated using Ruch et al. (1989) method. $1.0 \mathrm{~mL}$ extracts $(100-600 \mu \mathrm{g} / \mathrm{mL})$ were added to $3.0 \mathrm{~mL}$ hydrogen peroxide $(40 \mathrm{mM})$ prepared in phosphate buffer (50 mM, pH 7.4), incubated for $10 \mathrm{~min}$ at room temperature and the absorbance was measured at 230 nm after against a blank.

Hydrogen scavenging ability $=[($ Abs control - Abs sample $) /$ (Abs control) $] \times 100$

\section{Lipid peroxidation assay}

\section{Preparation of tissue homogenates}

The rats (12 weeks old and weighing between 220 and $240 \mathrm{~g}$ ) were decollated using mild diethyl ether as anaesthesia; the whole brain, pancreas and penile tissues were removed immediately, placed on ice and weighed. They were then homogenized in cold saline $(1: 10, \mathrm{w} / \mathrm{v})$ with 10 up and down strokes at $1200 \mathrm{rpm}$ in a Teflon glass homogenizer. The 
homogenate was centrifuged at $3000 \mathrm{x}$ g for $10 \mathrm{~min}$, the low speed supernatant (SI) was used for the Lipid peroxidation assay (Belle, et al., 2004).

\section{Lipid peroxidation and TBA reactions}

The lipid peroxidation assay was done according to the modified Ohkawa et al. (1979) method. Described thus, $100 \mu \mathrm{L}$ of the SI fraction was mixed with solution containing $30 \mu \mathrm{L}$ of $0.1 \mathrm{M}$ Tris- $\mathrm{HCl}$ buffer of $\mathrm{pH} 7.4,0-100 \mu \mathrm{L}$ extract and $30 \mu \mathrm{L}$ of $250 \mu \mathrm{M}$ freshly prepared $\mathrm{FeSO}_{4}$. Distilled water was used to make the volume to $300 \mu \mathrm{L}$, it was then incubated for 1 hour at $37^{\circ} \mathrm{C}$. $300 \mu \mathrm{L}$ of $8.1 \%$ sodium dodecyl sulphate (SDS) was added to the mixture containing SI for colour development; $600 \mu \mathrm{L}$ of acetic acid/ $\mathrm{HCl}$ mixture of $\mathrm{pH} 3.4$ and $600 \mu \mathrm{L}$ of $0.8 \%$ thiobarbituric acid (TBA) was added. The whole mixture was incubated for 1 hour at $100{ }^{\circ} \mathrm{C}$. Absorbance was measured at $532 \mathrm{~nm}$. Malondialdehyde (MDA) produced was calculated and expressed as \% control (Oboh et al., 2007).

\section{Statistical analysis}

The result was expressed as mean of triplicate determination \pm standard deviation. Spread sheet soft-ware (Microsoft Excel(C, version 2013) was used for the calculation of Standard deviations. Analysis of variance (ANOVA) was performed using Statistical Analysis System proprietary software (SAS, 2002). Duncan's multiple range tests was used for mean separation $(P<0.05)$. Graph pad 5.0. was used for the plotting of the graph. IC50 was calculated using a linear regression analysis.

\section{Results and discussion}

Total phenolics, total flavonoids and ascorbic acid of the different extracts of Ageratum conyzoides is presented in Table I. The total phenolic compound in the aqueous extracts is 48.9 while the methanol extract is 61.4 expressed in $\mathrm{mg}$ (GAE)/g. Ageratum conyzoides in the aqueous extracts and the methanol extract in this work exhibited a high phenolic content when compared with the phenolic contents of 56 selected Chinese medicinal plants, selected Nigerian, medicinal plants and that of traditional medicinal plant in
Ecuador (Feng-Lin Song et al., 2010; Agbo et al., 2015; Adriana et al., 2013). It is very low to the phenolic content of the leaf extract of Asplenium platyneuron $82.33 \mathrm{mg}$ GAE/g, Euphorbia prostrata $97.77 \mathrm{mg}$ GAE/g, Platycerium bifurcatum $87.62 \mathrm{mg}$ GAE/g (Agbo et al., 2015), Abarema cochliacarpos $120.39 \mathrm{mg}$ GAE/g and Stryphnodendron pulcherrimum $86.67 \mathrm{mg} \mathrm{GAE} / \mathrm{g}$ (Neto et al., 2016). One of the secondary metabolites found in plants are the Phenolic compounds; they are derived from phenylalanine and tyrosine. They possess very different antioxidant activities and they are very effective in chain breaking (Shahidi and Wansundeara, 1992; Naczk and Shahidi, 2004). The methanol extract in this work was observed to be significantly $(P<0.05)$ greater in phenolic content in comparison with the aqueous extract.

This result agrees with the report of other researchers where the methanol extract exhibited a higher phenolic content than other solvents used in the extraction of phenols (Ghasemzadeh et al., 2011; Ho et al., 2012; Miguel, et al., 2014; Do et al., 2014). That the methanol extract was higher in phenolic content than the aqueous extract could be because there are more non-phenolic compounds in aqueous extracts than in methanol extracts since phenol is frequently found connected to other biomolecules like polysaccharides, chlorophyll, proteins, terpenes, inorganic compounds and so on. There could be possible complex formation of some of these phenolic compounds in the extract which dissolve in methanol (Do et al., 2014).

The total flavonoid is expressed in $\mathrm{mg} / \mathrm{g}$ quercetin equivalents (QE). The flavonoid in Ageratum conyzoides leaves in the two extracts are higher than the flavonoids reported for some plants from Brazilian flora (Neto et al., 2016). It is very low when compared to the flavonoids of Asplenium platyneuron, Allamanda cathartica, Euphorbia prostrata, Platycerium bifurcatum (Agbo et al., 2015).The flavonoid content of Ageratum conyzoides is similar to that of total phenol with the methanol extract having the highest flavonoid content of $42.2 \mathrm{mg} \mathrm{QE} / \mathrm{g}$ which was significantly $(P$ $<0.05)$ higher than that of aqueous extract. It has been observed by Ghasemzadeh et al. (2011), Miguel et al. (2014) 
Table I. Total phenolics, flavonoid, ascorbic acid and phosphomolybdate of aqueous and methanol extracts of Ageratum conyzoides leaves

\begin{tabular}{llllll}
\hline & $\begin{array}{l}\text { Total } \\
\text { Phenolics } \\
\text { mg GAE/g }\end{array}$ & $\begin{array}{l}\text { Total } \\
\text { Flavonoids } \\
\text { mg QE/g }\end{array}$ & $\begin{array}{l}\text { Total Non } \\
\text { Flavonoids } \\
\text { mg QE/g }\end{array}$ & $\begin{array}{l}\text { Ascorbic acid } \\
\mathrm{mg} / 100 \mathrm{~g}\end{array}$ & $\begin{array}{l}\text { Phosphomolybdate } \\
\text { mg AAE/g }\end{array}$ \\
\hline Aqueous & $48.9 \pm 2.95 \mathrm{~b}$ & $18.7 \pm 0.91 \mathrm{~b}$ & $30.2 \pm 1.11 \mathrm{a}$ & $2.6 \pm 0.06 \mathrm{~b}$ & $33.5 \pm 1.86 \mathrm{~b}$ \\
Methanol & $61.4 \pm 8.64 \mathrm{a}$ & $42.2 \pm 6.25 \mathrm{a}$ & $19.2 \pm 0.87 \mathrm{~b}$ & $10.1 \pm 0.10 \mathrm{a}$ & $45.8 \pm 2.02 \mathrm{a}$ \\
\hline
\end{tabular}

Values represent mean \pm standard deviation of triplicate determination. Values with the same letter along the same column are not significantly different $(\mathrm{p}<0.05)$. GAE - Gallic Acid Equivalent, AAE - Ascorbic Acid Equivalent, QE - Quercetin Equivalent

and Do et al. (2014) that methanol extract has a higher flavonoid in comparison with other solvent used for extraction. Due to the phenolic nature of flavonoids, they are quite polar alright but very poor when dissolving in water (Miguel et al., 2014); this can explain the higher concentrations of flavonoids in methanol extracts than in the aqueous extracts. The total non-flavonoid content of Ageratum conyzoides (Table I) showed that the aqueous extract has significantly $(P<0.05)$ higher non-flavonoids content than the methanol extract. This showed that there are several classes of phenolic phytochemicals still present in the aqueous extract. Flavonoids are naturally present in plants and are thought to have positive impact on human health. There have been several reports on its high effectiveness in scavenging most oxidizing molecules that includes singlet oxygen, and other free radicals that have been implicated in several diseases (Bravo, 1998).

The ascorbic acid of the aqueous extract of Ageratum conyzoides leaves was found to be $2.6 \mathrm{mg} / 100 \mathrm{~g}$ and the methanol extract $10.1 \mathrm{mg} / 100 \mathrm{~g}$. Ageratum conyzoides leaves extract contain a very low ascorbic acid when compared with the ascorbic acid of some medicinal plants in Nigeria, Manipur and Pakistan (Okerie and Alonge, 2006; Okram et al., 2016; Iqbal et al., 2011). Ascorbic acid has been observed to be a powerful antioxidant because it can donate a hydrogen atom thereby forming a stable ascorbyl free radical. It scavenges reactive oxygen and nitrogen oxide species, also very effective in combating superoxide radical ion, hydrogen peroxide and hydroxyl radicals (Weber et al., 1996). Ascorbic acid should be more soluble in water than methanol, though methanol is a polar solvent. This result is contrary, the ascorbic acid in this work was observed to be higher in methanol extract of Ageratum conyzoides than the aqueous extract. The reason for this result cannot be categorically explained.

One electron transfer (ET) and hydrogen atom transfer

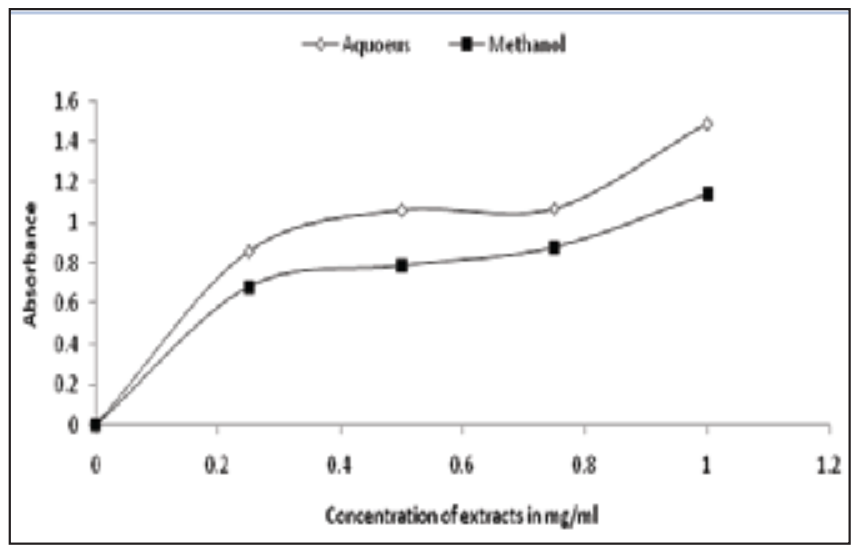

Fig. 1. Reducing ability of the aqueous and methanol extracts of Ageratum conyzoides leaves. Values represent mean \pm standard deviation of triplicate determination

(HAT) made up the antioxidant capacity assays; HAT and ET assays measures the radical (or oxidant) scavenging capacity of samples and they do not look into the preventive antioxidant capacity of samples.ET assays are much more easier to evaluate than HAT assays because it involved colour development as the oxidant is reduced (Phatak and Hendre, 2014; Huang et al., 2005). ET assays of reducing power, 
Table II. IC50 of reducing power, iron chelating ability, hydrogen peroxide $\left(\mathrm{H}_{2} \mathrm{O}_{2}\right)$ scavenging ability and inhibition of $\mathrm{Fe}^{2+}$ induced MDA Production of Aqueous and Methanol extracts of Ageratum conyzoides leaves

\begin{tabular}{lllllll}
\hline & $\begin{array}{l}\text { Reducing } \\
\text { power } \\
\mathrm{mg} / \mathrm{ml}\end{array}$ & $\begin{array}{l}\text { Iron } \\
\text { chelating } \\
\text { ability } \\
\mathrm{mg} / \mathrm{ml}\end{array}$ & $\begin{array}{l}\mathrm{H}_{2} \mathrm{O}_{2} \\
\text { scavenging } \\
\text { ability } \mu \mathrm{g} / \mathrm{ml}\end{array}$ & $\begin{array}{l}\text { MDA } \\
\text { pancreas } \\
\mu \mathrm{g} / \mathrm{ml}\end{array}$ & $\begin{array}{l}\text { MDA } \\
\text { Brain } \mu \mathrm{g} / \mathrm{ml}\end{array}$ & $\begin{array}{l}\text { MDA penile } \\
\text { tissue } \mu \mathrm{g} / \mathrm{ml}\end{array}$ \\
\hline Aqueous & $32.86 \pm 1.95 \mathrm{a}$ & $1.7 \pm 0.01 \mathrm{~b}$ & $1052.40 \pm 37.29 \mathrm{~b}$ & $105.32 \pm 4.2 \mathrm{~b}$ & $91.74 \pm 3.1 \mathrm{a}$ & $115.9 \pm 4.9 \mathrm{~b}$ \\
Methanol & $42.59 \pm 2.72 \mathrm{~b}$ & $1.23 \pm 0.01 \mathrm{a}$ & $946.40 \pm 23.12 \mathrm{a}$ & $94.21 \pm 3.1 \mathrm{a}$ & $108.69 \pm 4.6 \mathrm{~b}$ & $75.95 \pm 2.2 \mathrm{~b}$
\end{tabular}

Values represent mean \pm standard deviation of triplicate determination. Values with the same letter along the same column are not significantly different $(\mathrm{p}<0.05)$. MDA- malondialdehyde

metal chelating ability, hydrogen peroxide scavenging ability, 1,1-diphenyl 2 picrylhydrazyl (DPPH) radical scavenging ability and the phosphomolybdate method were selected for the measurement of total antioxidant capacity in Ageratum conyzoides leaves extracts.

The reducing power of Ageratum conyzoides leaves extracts was based on the capacity of the extract to reduce the transition metal $\mathrm{Fe}^{3+}$ by electron transfer to $\mathrm{Fe}^{2+}$. A higher absorbance at $700 \mathrm{~nm}$ is an indication of a higher activity (Zarena and Sankar, 2009). The reducing power of Ageratum conyzoides leave extracts in Figure 1 shows to be dose dependent with the aqueous extract exhibiting the highest reducing power as the concentration of extracts increases from $0.25 \mathrm{mg} / \mathrm{mL}$ to $1.0 \mathrm{mg} / \mathrm{mL}$. However, the reducing power of A. conyzoides of aqueous extract was high but statistically not significantly $(P<0.05)$ higher than the reducing power of methanol extract. The IC50 value for the reducing power (Table II) of aqueous extract of $A$. conyzoides is $32.86 \mathrm{mg} / \mathrm{mL}$ which was significantly $(P<0.05)$ lower than $42.59 \mathrm{mg} / \mathrm{mL}$ for the methanol extract. A lower IC50 value is an indication of a stronger antioxidant activity. The reducing power capacity showed that the antioxidant compounds can donate electron which can cause reduction in the oxidized intermediates produced during the process of lipid peroxidation (Tachakittirungrod et al., 2007).

However, the reducing power assay is disadvantaged in that any electron-donor which has a redox potential that are lower than the redox pair $\mathrm{Fe}^{3+} / \mathrm{Fe}^{2+}$ can contribute to the reducing power value and this will give a falsely high values even if they do not have antioxidant properties (Nilsson et al., 2005).

Bivalent transition metal ion $\mathrm{Fe}^{2+}$ serves as catalysts of

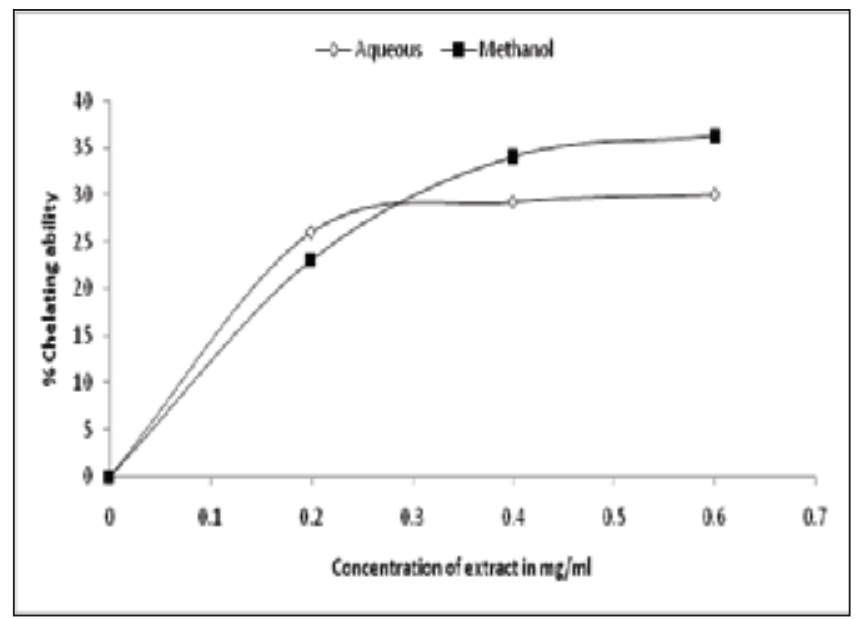

Fig 2. Metal Chelating ability of aqueous and methanol extracts of Ageratum conyzoides leaves. Values represent mean \pm standard deviation of triplicate determination

oxidative processes, that give rise to the formation of hydroxyl $\mathrm{OH} \bullet$ radicals through Fenton chemistry (Halliwell, 1997). This reaction can be prevented by iron chelation and deactivation. The ability of the extracts of $A$. conyzoidesto chelate $\mathrm{Fe}^{2+}$ ions was evaluated and the result is presented in Fig. 2. The methanol extracts of Ageratum conyzoides leaves showed the best iron chelating ability as the concentration of extracts increases from $0.2 \mathrm{mg} / \mathrm{mL}$ to $0.6 \mathrm{mg} / \mathrm{mL}$ which was significantly $(P<0.05)$ higher than that of the aqueous extract. The IC50 value for the chelating ability (Table II) of methanol 
extract of $A$. conyzoides is $1.23 \mathrm{mg} / \mathrm{mL}$ which was significantly $(P<0.05)$ lower than $1.7 \mathrm{mg} / \mathrm{mL}$ for the aqueous extract. It is expected that methanol extracts would have a high chelating ability because of its high phenolic and flavonoid content which has been positively correlated to the iron chelating activity (Al-Farga et al., 2014; Hinneburg et al., 2006).

Hydrogen peroxide $\mathrm{H}_{2} \mathrm{O}_{2}$ occasionally can be toxic to cell

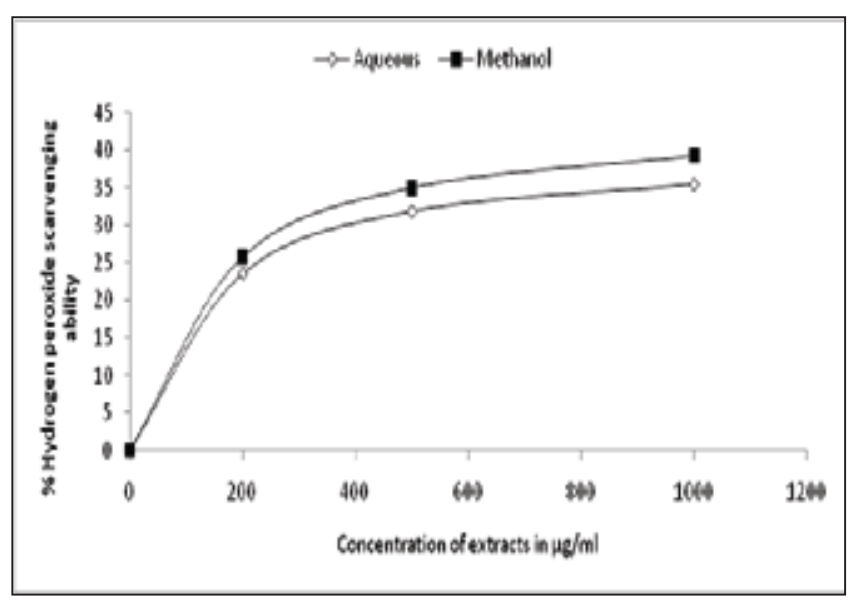

Fig 3. Hydrogen peroxide scavenging ability of aqueous and methanol extracts of Ageratum conyzoides leaves. Values represent mean \pm standard deviation of triplicate determination

because it may lead to the formation of hydroxyl $\mathrm{OH} \bullet$ radical in the cells that can cause initiation of lipid peroxidation and result in DNA damage (Halliwell, 1991; Sahreen et al., 2011), the removal of this $\mathrm{H}_{2} \mathrm{O}_{2}$ before it causes damage is an important step in antioxidant defence of cell or food systems. As depicted in Fig. 3, the extracts of Ageratum conyzoides leaves exerted a concentration-dependent scavenging of hydrogen peroxide $\left(\mathrm{H}_{2} \mathrm{O}_{2}\right)$. The methanol extracts of Ageratum conyzoides leaves showed the best hydrogen peroxide $\left(\mathrm{H}_{2} \mathrm{O}_{2}\right)$ scavenging ability as the concentration of extracts increases from $200 \mu \mathrm{g} / \mathrm{mL}$ to $1000 \mu \mathrm{g} / \mathrm{mL}$ which was significantly $(P<0.05)$ higher than that of the aqueous extract. The IC50 value (Table II) of methanol extract of Ageratum conyzoides is $946.4 \mu \mathrm{g} / \mathrm{mL}$ which was significantly $(P<0.05)$ lower when compared to $1052.4 \mu \mathrm{g} / \mathrm{mL}$ for the aqueous extract. The best activity found in the methanol extract of Ageratum conyzoides leaves may be related to their higher content of phenols and flavonoids which has the ability to donate electrons to $\mathrm{H}_{2} \mathrm{O}_{2}$ and thus converting it to water (Shahriar et al., 2012).

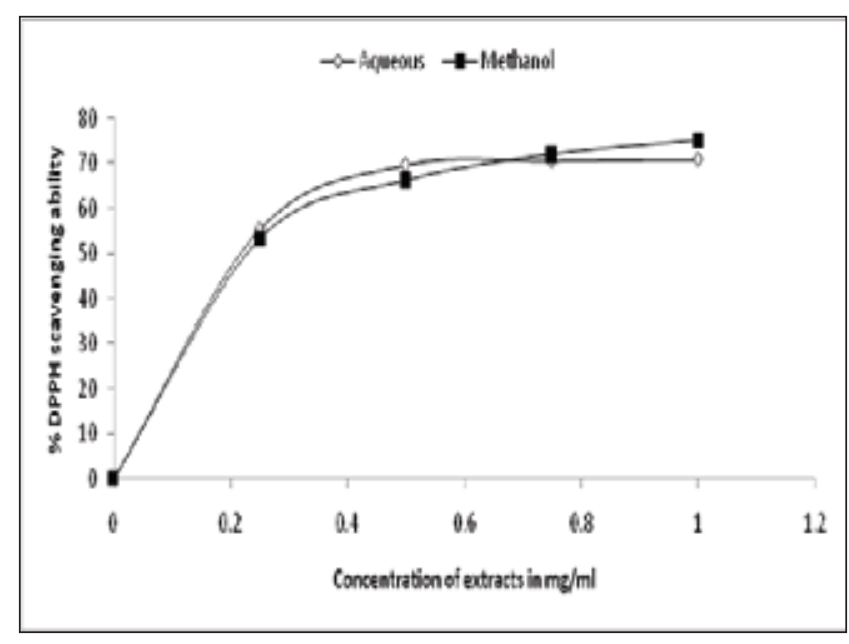

Fig 4. DPPH radical scavenging ability of aqueous and methanol extracts of Ageratum conyzoides leaves. Values represent mean \pm standard deviation of triplicate determination

The DPPH results are very important in confirming the results obtained in total phenolic content (Palafox Carlos et al., 2012). The DPPH radical- scavenging ability of $A$. conyzoides leave extract at $0.25-1.0 \mathrm{mg} / \mathrm{mL}$ concentrations was measured and the results are presented in Fig. 4. A dose-response relationship was found in the DPPH radical-scavenging ability of $A$. conyzoides leave extracts; the ability increased with an increase in the concentration of the A. conyzoides leave extracts. The methanol extracts of Ageratum conyzoides leaves recorded the highest DPPH radical-scavenging ability which was significantly $(P<0.05)$ higher than the aqueous extract.

The total antioxidant capacity of Ageratum conyzoides leaves extracts is presented in Table I and expressed as $\mathrm{mg} / \mathrm{g}$ ascorbic acid equivalents (AAE). The phosphomolybdenum method was used for the total antioxidant capacity evaluation; this is based on the reduction of Mo (VI) to Mo (V) by the antioxidant compound of the extract forming a green phosphomolybdate (V) complex and then evaluated spectrophotometrically (Prieto et al., 1999). This reduction can be caused by natural products like phenols and flavonoids. The total antioxidant capacity (TAC) of the extracts was higher in methanol extracts of Ageratum 
conyzoides leaves (45.8 $\mathrm{mg} \mathrm{AAE} / \mathrm{g}$ ) than the aqueous extract (33.5 mg AAE/ g). In the same trend of hydrogen peroxide scavenging ability and DPPH assays, the methanol extracts of Ageratum conyzoides leaves had a higher TAC; in addition they also have a higher total phenolic and flavonoid content. The high phenolic content of the methanol extracts of Ageratum conyzoides leaves is an indication of high antioxidant capacity since the phenolic compound reacts with radicals like hydroxyl radical, superoxide anion radical and lipid peroxide radical. It has been revealed that there is high correlation between antioxidant capacity and phenolic content of samples (Aliyu et al., 2011). Recent study showed that many flavonoid compounds and polyphenols contribute significantly to the phosphomolybdate reduction activity of medicinal plants (Khan et al., 2012). It is to be noted that the possible antioxidant qualities of plant extracts does not only depend on its phytochemical composition but also on the extraction systems which may include methods, duration and polarity of organic solvents (Wong et al., 2006).

Parkinson's as well as Alzheimer's disease is a neurological disorder that often be the cause of erectile dysfunction ED since they cause decrease in libido or inability to kick start the erectile process (Eleazua et al., 2017). The polyunsaturated fatty acids (PUFAs) in the brain membranes are very rich in phospholipids and they are subject to free radicals attacks easily, leading to oxidative damage in the brain phospholipids which could lead to the development of Alzhemier's disease (Axelsen et al., 2011). Vasculogenic erectile dysfunction ED is caused by diabetes mellitus. In diabetes, an increased level of ROS causes the activation of Rho-kinase 2 which increases the contraction of the corpus cavernosum (CC) smooth muscles. This ROS under diabetes also inhibit the endothelial nitric oxide synthase NOS, thereby causing a decrease in the CC smooth muscle relaxation. (Eleazua et al., 2017).

The accumulation of $\mathrm{Fe}^{2+}$, in the islets of Langerhan of the pancreas, causes oxidative destruction of the $\beta$-cells of the pancreas thereby impairing the pancreas from its functions and leading to diabetic melitus (Shah and Fonseca, 2011). The ability of Ageratum conyzoides leaves extracts to protect

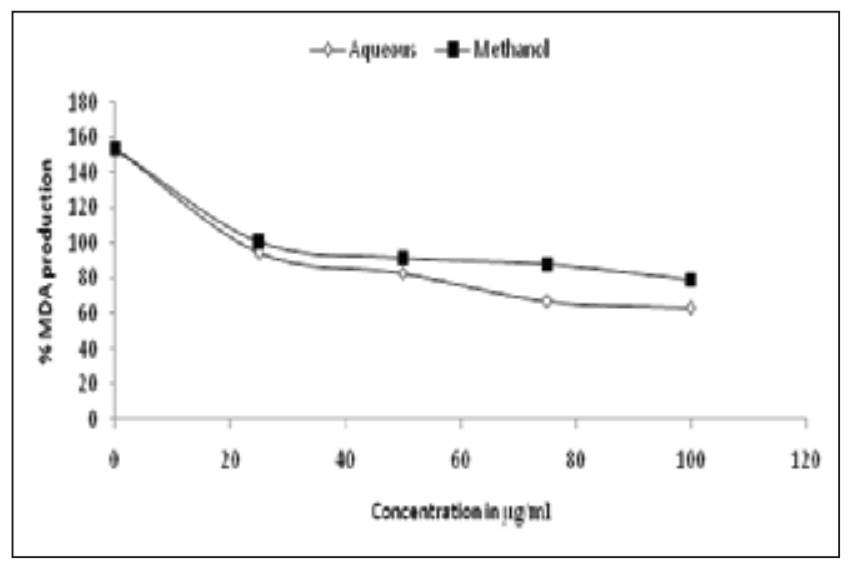

Fig. 5. Inhibition of $\mathrm{Fe}^{2+}$ induced MDA production in rat brain by the aqueous and methanol extracts of Ageratum conyzoides leaves. Values represent mean \pm standard deviation of triplicate determination

cultured rat brain and pancreas against $\mathrm{Fe}^{2+}$ induced lipid peroxidation is shown in Fig. 5 and 6. Incubation of rat's brain and pancreas in the presence Sof $250 \mu \mathrm{M}$ iron (II) has caused a significant increase in the MDA content of these two organs: $153.41 \%$ in the brain and $130.39 \%$ in the pancreas. The formation of reactive oxygen species (ROS) facilitates lipid peroxidation through the Fenton reaction and it could have accounted for the increase in MDA contents of these organs after incubation in the presence of $\mathrm{Fe}^{2+}$. The addition of the Ageratum conyzoides leaves extracts (aqueous and methanol) significantly $(P<0.05)$ inhibited MDA production in the brain and pancreas in a dose dependent manner. The methanol extract exhibited a higher inhibitory effect on the $\mathrm{Fe}^{2+}$ induced lipid peroxidation in rat pancreas with IC50 of $94.21 \mu \mathrm{g} / \mathrm{mL}$ against $111.65 \mu \mathrm{g} / \mathrm{mL}$ for aqueous extract (Table II) while the aqueous extract showed a higher inhibitory effect on $\mathrm{Fe}^{2+}$ induced lipid peroxidation in rat brain with IC50 of $91.74 \mu \mathrm{g} / \mathrm{mL}$ against $110.82 \mu \mathrm{g} / \mathrm{mL}$ for methanol extract (Table II). The possible way by which these extracts protect the organs could be by $\mathrm{Fe}^{2+}$ chelation and the scavenging of the hydroxyl radical (Ademosun and Oboh, 2014). The ability of the Ageratum conyzoides leaves extracts, both aqueous and methanol, to inhibit $\mathrm{Fe}^{2+}$ induced lipid peroxidation in the brain and pancreas homogenate implied that the extract could prevent the oxidative damage of the brain and pancreas cells thereby preventing the development of Alzheimer's diseases and diabetic mellitus 


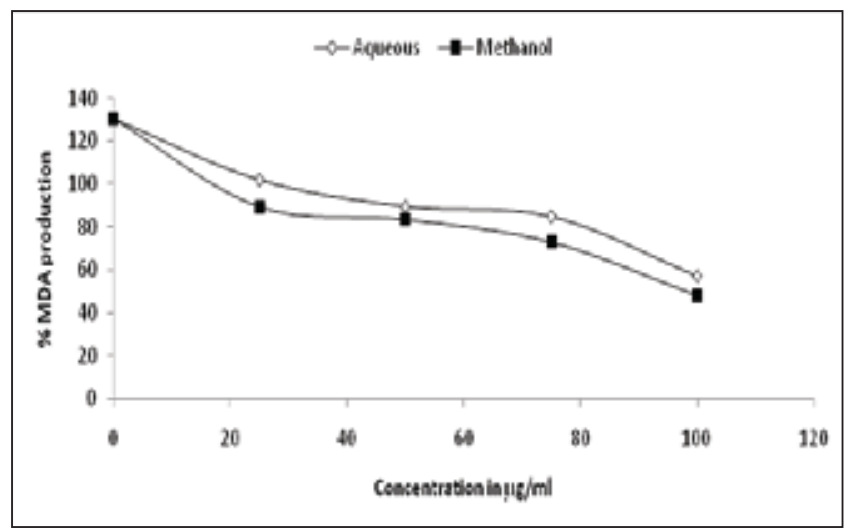

Fig. 6. Inhibition of $\mathrm{Fe}^{2+}$ induced MDA production in rat pancreas by the aqueous and methanolic extracts of Ageratum conyzoides leaves. Values represent mean \pm standard deviation of triplicate determination

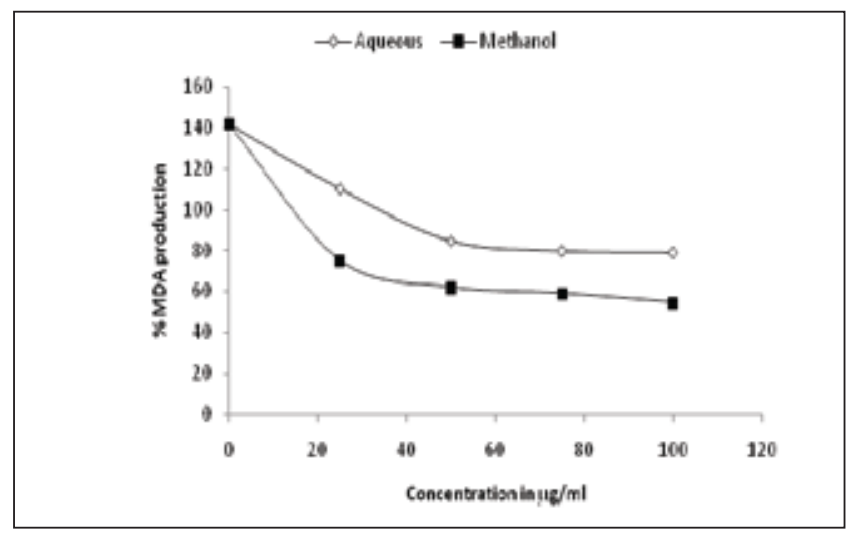

Fig. 7. Inhibition of $\mathrm{Fe}^{2+}$ induced MDA production in rat penile tissue by the aqueous and methanolic extracts of Ageratum conyzoides leaves. Values represent mean \pm standard deviation of triplicate determination

that could cause neurogenic and Vasculogenic erectile dysfunction ED. The MDA level in the penile tissue was observed to have been elevated to $141.46 \%$ after the rat penile tissue homogenate was incubated in the presence of $250 \mu \mathrm{M} \mathrm{Fe}^{2+}$ (figure 3). This is an indication of oxidative damage in the penile tissue caused by free radicals generated by $\mathrm{Fe}^{2+}$ which could be the breakdown of $\mathrm{H}_{2} \mathrm{O}_{2}$ to generate $\mathrm{OH}$ radical that can cause injuries to the penile tissues (Oboh et al., 2017). The aqueous and methanol extracts of Ageratum conyzoides leaves caused a significant $(P<0.05)$ decrease in the MDA level in a manner that is dose dependent. The methanol extracts showed a higher inhibition of $\mathrm{Fe}^{2+}$-induced lipid peroxidation in the penile tissue of rat with IC50 of $75.95 \mu \mathrm{g} / \mathrm{mL}$ (Table II) than did the aqueous extracts with IC50 of $115.9 \mu \mathrm{g} / \mathrm{mL}$ (Table II). MDA produced as a result of oxidative stress in the penile tissue causes decrease in the bioavailability of $\mathrm{NO}$ and low levels of NO result in impairment of the guanyl cyclase/cGMP pathway which is an important pathway in penile erection by interacting with ROS (superoxides) to form toxic peroxynitrites (Akomolafe et al., 2017). The inhibition of $\mathrm{Fe}^{2+}$-induced lipid peroxidation in penile tissue homogenates by the extracts of Ageratum conyzoides indicates that the extract could prevent peroxynitrite-induced MDA production and by implication NO will be more bio-available to mediate in the erectile process thereby preventing ED.

Conclusively, in the present study, the aqueous and methanol extracts of Ageratum conyzoides leaves showed a considerable antioxidant and anti-lipid peroxidation activities but methanol extract has a higher activity. Hence, these extracts of Ageratum conyzoides leaves can be used as potent natural antioxidant against free radicals and lipid peroxidation of organs and prevent erectile dysfunction ED.

\section{References}

Abena AA, Ouamba JM and Keita A (1996), Antiinflammatory, analgesic and antipyretic activities of essential oil of Agereatum conyzoides, Phytoterapy Research 10: S164-S165.

Adebayo AH, Tan NH and Zhang YM (2010), Anticancer and antiradical scavenging activity of Ageratum conyzoides L. (Asteraceae), Pharmacogn. Mag. 6(21): 62-66.

Adefegha SA, Oboh G, Oyeleye SI and Ejakpovi I (2016), Erectogenic, antihypertensive, antidiabetic, antioxidative properties and phenolic compositions of almond fruit (terminalia catappa 1.) parts (hull and drupe) - in vitro, Journal of Food Biochemistry 1 12. DOI: $10.1111 /$ jfbc. 12309

Ademosun AO and Oboh G (2014), Anticholinesterase and antioxidative properties of water-extractable phytochemicals from some citrus peels, Journal of basic and clinical physiology and pharmacology 25(2): 99-204. DOI: 10.1515/jbcpp-2013-0027 
Adriana J, Yeray R, Jorge C, Maria EC, Margarita G and Luis A (2013), Antioxidant activity and total phenolics of plants used in traditional medicine in Ecuador, The $17^{\text {th }}$ international electronic conference on synthetic organic chemistry. DOI: 10.3390/ecsoc/17-b001

Agarwal A, Nandipati KC, Sharma RK, Zippe CD and Raina R (2006), Role of oxidative stress in the pathophysiological mechanism of erectile dysfunction, Journal of Andrology 27(3): 335-347. DOI: 10.2164/jandrol.05136

Agbafor KN, Engwa AG, Ude CM, Obiudu IK and Festus BO (2015), The effect of aqueous leaf extract of Ageratum conyzoides on blood glucose, creatinine and calcium ion levels in albino rats, Journal of Pharmaceutical Chemical and Biological Sciences 3(3): 408-415.

Agbo MO, Uzor PF, Akazie-Nneji UN, Eze-Odurukwe CU, Ogbatue UB and Mbaoji EC (2015), Antioxidant, total phenolic and flavonoid content of selected nigerian medicinal plants, Dhaka Univ. Journal of Pharmceutical Science 14(1): 01-07.

Akomolafe S, Oboh G, Olasehinde T, Oyeleye S and Ogunsuyi O (2017), Modulatory effects of Aqueous extract from Tetracarpidium conophorum leaves on key enzymes linked to erectile dysfunction and oxidative stress-induced lipid peroxidation in penile and testicular tissues, Journal of Applied Pharmaceutical Science 7(01): 051-056. DOI: 10.7324/JAPS.2017.70107

Axelsen PH, Komatsu H and Murray IVJ (2011), Oxidative stress and cell membranes in the pathogenesis of alzheimer's disease, Physiology 26(1): 54-69. DOI: 10 $.1152 /$ physiol.00024.2010

AL-Farga A, Hui Z and Azhari S (2014), In vitro antioxidant activity and total phenolic and flavonoid contents of Alhydwan (Boerhavia elegana Choisy) seeds, Journal of Food and Nutrition Research 2: 215-220.

Aliyu AB, Ibrahim MA, Musa AM, Bulus T and Oyewale AO (2011), Phenolics content and antioxidant capacity of extracts and fractions of Verninia blumeoides (Asteraceae), International Journal of Biological Chemistry 5: 352-359.

Belle NAV, Dalmolin GD, Fonini G, Rubin MA and Rocha JB T (2004), Polyamines reduces lipid peroxidation induced by different pro-oxidant agents, Brain Research 1008(2): 245-251. DOI: 10.1016/ j.brainres. 2004.02.036
Bravo L (1998), Polyphenols: chemistry, dietary sources, metabolism and nutritional significance, Nutr Reviews 56: $317-333$.

Dinis TCP, Madeira VMC and Almeida LM (1994), Action of phenolic derivatives (acetaminophen, salicylate and 5-aminosalicylate) as inhibitors of membrane lipid peroxidation and as peroxy radical scavengers, Arch. Biochemistry and Biophysics 315: 161-169.

Do QD, Angkawijaya AE, Tran-Nguyen PL, Huynh LH, Soetaredjo FE, Suryadi Ismadji S and Ju Y (2014), Effect of extraction solvent on total phenol content,total flavonoid content, and antioxidant activity of Limnophila aromatic, Journal of food and drug analysis 22: 296 -302.

Eleazua C, Obianujua N, Eleazub K and Kaluc W (2017), The role of dietary polyphenols in the management of erectile dysfunction-Mechanisms of action, Biomedicine and Pharmacotherapy 88: 644-652. DOI: org/10.1016/j.biopha. 2017.01.125 0753-3322

Feng-Lin Song, Ren-You Gan, Yuan Zhang, Qin Xiao, Lei Kuang and Hua-Bin Li (2010), Total phenolic contents and antioxidant capacities of selected Chinese medicinal plants, International Journal of Molecular Sciences 11: 2362-2372. DOI: 10.3390/ijms 11062362

Ferreira A, Proenc C, Serralheiro MLM and Arajo MEM (2006), The in vitro screening for acetylcholinesterase inhibition and antioxidant activity of medicinal plants from Portugal, Journal of Ethnopharmacology 108: 31-37.

Ghasemzadeh A, Jaafar HZE and Rahmat A (2011), Effects of solvent type on phenolics and flavonoids content and antioxidant activities in two varieties of young ginger (Zingiber officinale Roscoe) extracts, Journal of Medicinal Plants Research 5(7): 1147-1154.

Gyamfi MA, Yonamine M and Aniya Y (1999), Free radical scavenging action of medicinal herbs from Ghana: Thonningia sanguine on experimentally induced liver injuries, General Pharmacology 32(6): 661-667.

Haffner SM, Lehto S, Ronnemaa T, Pyorala K and Laakso M (1998), Mortality from coronary heart disease in subjects with type- 2 diabetes and in non-diabetic subjects with and without prior myocardial infarction, New English Journal of Medicine 339: 229-234. 
Halliwell B (1991), Reactive oxygen species in living systems: Biochemistry and role in human disease, American Journal of Medicine 91: 14-22.

Halliwell B (1997), Antioxidants: the basics - what they are and how to evaluate them, Advances in Pharmacology 38: 3-20.

Hinneburg I, Damien Dorman HJ and Hiltunen R (2006), Antioxidant activities of extracts from selected culinary herbs and spices, Food Chemistry 97: 122-129.

Ho Y, Huang S, Deng J, Lin Y, Chang Y and Huang G (2012), In vitro antioxidant properties and total phenolic contents of wetland medicinal plants in Taiwan, Botanical Studies 53: 55-66.

Huang D, Ou B and Prior RL (2005), The Chemistry behind Antioxidant Capacity Assays, Journal of Agricultural Food Chemistry 53: 1841-1856.

Iqbal H, Riaz U, Rooh U, Muhammad K, Naseem U, Abdul B, Farhat A, Muneeb R, Mohammed Z, Jehangerir K and Naeem K (2011), Phytochemical analysis of selected medicinal plants, African Journal of Biotechnology 10 (38): 7487-7492.

Ita SO, Etim OE, Ben EE, Ekpo OF, (2007), Haematopoietic properties of ethanolic leaf extract of Ageratumconyzoides (goat weed) in albino rats, Nigerian Journal of Physiological Science 22(1-2): 83-87.

Kassier SM and Veldman FJ (2014), When science meets culture: The prevention and management of erectile dysfunction in the 21st century, South African Journal of Clinical Nutrition 27: 7-12.

Khan RA, Khan MR and Sahreen S.(2012), Assessment of flavonoids contents and in vitro antioxidant activity of Launaea procumbens. Chemistry Central Journal 6(1): 43.

Kim DO, Chun OK, Kim YJ, Moon HY and Lee CY (2003), Quantification of polyphenolics and their antioxidant capacity in fresh plums, Journal of Agriculture Food and Chemistry 516: 509-6515.

Miguel MA, Nunes S, Dandlen SA, Cavaco AM and Antunes MD (2014), Phenols, flavonoids and antioxidant activity of aqueous and methanolic extracts of propolis (Apis mellifera L.) from Algarve, South Portugal, Food Sci. Technol. Campinas 34(1): 16-23.
Mitra P, Ghosh T and Mitra PK (2015), Isolation of antiulcerogenic compound (ac-i) from ageratum conyzoides leaves and effect of season on yield of the compound, SMU Medical Journal 2(1): 221-237.

Naczk M and Shahidi F (2004), Extraction and analysis of phenolics in food, Journal of Chromatography 1054: 95-111.

Neto JL, Dias de Araújo Uchôa A, Andrade de Moura P, Filho CMB, Tenório JCG, Gomes da Silva A, Ximenes RM, Vanusa da Silva M and Correia MTD (2016), Phytochemical screening, total phenolic content and antioxidant activity of some plants from Brazilian flora, Journal of Medicinal Plants Research 10(27): 409-416. DOI: 10.5897/JMPR2015.5979

Nilsson J, Pillai D, Onning G, Persson C, Nilsson A and Akesson B (2005), Comparison of the 2, 2'-azinobis-3-ethylbenzotiazoline-6-sulfonic acid (ABTS) and ferric reducing antioxidant power (frap) methods to asses the total antioxidant capacity in extracts of fruit and vegetables, Molecular Nutrition \& Food Research 49(3): 239-246. DOI: $10.1002 / \mathrm{mnfr} .200400083$

$\mathrm{NIH}$ Consensus Conference (1993), Impotence. NIH consensus development panel on impotence, JAMA 270: 83-90.

Oboh G, Puntel RL and Rocha JBT (2007), Hot pepper (Capsicum annuum, Tepin and Capsicum chinese, Habanero) prevents $\mathrm{Fe} 21$-induced lipid peroxidation in Brain - in vitro, Food Chem. 102: 178-185.

Oboh G, Adebayo AA, Ademosun AO and Boligon AA (2017), In vitro inhibition of phosphodiesterase-5 and arginase activities from rat penile tissue by two Nigerian herbs (Hunteria umbellate and Anogeissus leiocarpus), Journal of Basic Clinical Physiology 28(4): 393-401. DOI: 10.1515/jbcpp-2016-0143

Ohkawa H, Ohishi N and Yagi K (1979), Assay for lipid peroxides in animal-tissues by thiobarbituric acid reaction, Analytical Biochemistry 95(2): 351-358. DOI: $10.1016 / 0003-2697(79) 90738-3$

Okeri HA and Alonge PO (2006), Determination of the ascorbic acid content of two medicinal plants in Nigeria, Pakistan Journal of Pharmaceutical Science 19(1): 39-44. 
Okram AD, Mamoni D, Ananta S and Pranati D (2016), Ascorbic acid and tocopherol content of ten medicinal plant extracts of Manipur having anti-inflammatory properties, International Journal of Home Science 2(1): 308-312.

Okunade AL (2002), Ageratum conyzoides L. (Asteraceae), Fitoterapia 73: 1-16.

Oyaizu M (1986), Studies on products of browning reactions: Antioxidant activities of products of browning reaction prepared from glucose amine, Japanese Journal of Nutrition 44: 307-315.

Palafox-Carlos H, Yahia E, Islas-Osuna MA, Gutierrez-Martinez P, Robles-Sanchez $\mathrm{M}$ and Gonzalez-Aguilar GA (2012), E_ect of ripeness stage of mango fruit (Mangifera indica L, cv. ataulfo) on physiological parameters and antioxidant activity, Scientia Horticulturae 135: 7-13. DOI: 10.1016/ j.scienta.2011.11.027

Park YS, Jung ST, Kang SG, Heo BK, Arancibia-Avila P, Toledo F, Drzewiecki J, Namiesnik J and Gorinstein S (2008), Antioxidants and proteins in ethylene-treated kiwifruits, Food Chemistry 107: 640-648.

Phatak RS and Hendre AS (2014), Total antioxidant capacity (TAC) of fresh leaves of Kalanchoe pinnata, Journal of Pharmacognosy and Phytochemistry 2: 32-35.

Prieto P, Pineda M and Aguilar M (1999), Spectrophotometric quantitation of antioxidant capacity through the formation of a phosphomolybdenum complex: specific application to the determination of vitamin E, Analytical Biochemistry 269: 337-341.

Ruch RJ, Cheng SJ and Klaunig JE (1989), Prevention of cytotoxicity and inhibition of intercellular communication by antioxidant catechins isolated from Chinese green tea, Carcinogen 10: 1003-1008.

Rutkowski M and Grzegorczyk K (2007), Modifications of spectrophotometric methods for antioxidative vitamins determination convenient in analytic practice, acta sci. pol. technol. aliment. 6(3): 17-28.

Sahreen S, Khan MR and Khan RA (2011), Phenolic compounds and antioxidant activities of Rumex hastatus D. Don. leaves, Journal of Medicinal plants research 5: 2755-2765.
Shahidi F and Wanasundara PKJ (1992), Phenolic antioxidants, Food Science and Nutrition 32: 67-103.

Shahriar M, Akhter S, Hossain MI, Haque MA and Bhuiyan MA (2012), Evaluation of in vitro antioxidant activity of bark extracts of Terminalia arjuna, Journal of Medicinal Plants Research 6(39): 5286-5298.

Shah SV and Fonseca VA (2011), Iron and diabetes revisited, Diabetes Care 34(7): 1676-1677. DOI: $10.2337 / \mathrm{dc} 11-0700$

SAS (2002), Statistical Analysis System Proprietary software, Release 8.3. SAS Institute Inc., Carry, $\mathrm{NC}$.

Sasatomi K, Hiragata S, Miyazato M, Chancellor BM, Morris S and Yoshimura N (2008), Nitric oxide mediated suppression of detrusor overactivity by arginase inhibitor in rats with chronic spinal cord injury, Urol 72: 696-700.

Tachakittirungrod S, Okonogi S and Chowwanapoonpohn S (2007), Study on antioxidant activity of certain plants in thailand: mechanism of antioxidant action of guava leaf extract, Food Chemistry 103(2): 381-388. DOI: 10.1016/j.foodchem. 2006.07.034

Vaidyaratnam, Varier PS (2002), Indian Medicinal Plants- A Compendium of 500 species, I, Orient longman publishing house, Kolkatta, India, p 146.

Weber P, Bendich A and Schalch E (1996), Ascorbic acid and human health - a review ofrecent data relevant to human requirements, International Journal of Vitamin and Nutritional Research 66: 19-30.

Wong SP, Leong LP and William-Koh JH (2006), Antioxidant activities of aqueous extracts of selected plants, Food Chemistry 99(4): 775-783.

Zarena AS and Sankar KU (2009), A study of antioxidant properties from Garcinia mangostana 1. pericarp extract, Acta Scientiarum Polonorum Technologia Alimentaria 8(1): 23-34. 